\title{
39. STUDY OF GEOCHEMICAL DATA (EOCENE-SANTONIAN SAMPLES) FROM HOLE 516F (LEG 72) BY THE METHOD OF CORRESPONDENCE ANALYSIS ${ }^{1}$
}

\author{
Maurice Renard and Daniel Ambroise, Université Pierre et Marie, Curie, 75230 Paris Cedex 05, France
}

\section{INTRODUCTION}

This study involves samples of Santonian to Eocene age (Cores $516 \mathrm{~F}-125$ to $516 \mathrm{~F}-38$ ) taken from the Rio Grande Rise in the South Atlantic Ocean. These samples are from DSDP Site 516 occupied during Leg 72 of the Glomar Challenger (details given in site chapter, Site 516, this volume). Only Santonian to Paleocene cores have been well sampled, and analyses of the Eocene samples are preliminary results. Results of the trace element analyses ( $\mathrm{Mg}, \mathrm{Sr}, \mathrm{Mn}, \mathrm{Ni}, \mathrm{Fe}, \mathrm{Na}, \mathrm{K})$ of the carbonate fraction and $\mathrm{CaCO}_{3}$ percentage for each sample can be found in Renard and others (this volume). Whole geochemical data are treated by the statistical method of correspondence analysis. Oxygen and carbon isotopic ratios measured on samples close to the Cretaceous/ Tertiary boundary are not used in this study.

\section{METHOD}

The method of correspondence analysis is particularly well suited to interpretation of sedimentologic and geochemical data (Chenet and Teil, 1979; Rabussier, 1980; Ambroise et al., 1977; Tourenq, Ambroise, and Rohrlich, 1978). The mathematical theory is discussed in Benzecri (1973), Teil (1975), and Lebart and others (1980). In brief, correspondence analysis can be considered to be a variant of principal component analysis, in which the distance used for the calculation of the matrix is the metric $\chi^{2}$ distance. Results are plotted on bivariate graphs representing two factorial axes. By means of the $\chi^{2}$ distance, it is possible to project variable points and sample points simultaneously on the same graph. Thus, it is relatively easy to interpret the meaning of each axis and the relative positions of variable points and sample points. Each variable is "weighted" to have the same importance in the analytic results. Some of the variables show low "mass" values (numerous zero values, such as nickel and chromium) or are unreliable (such as potassium, which can be flushed out of clay minerals during acetic acid dissolution of carbonate) and are only used as illustrative variables (i.e., these variables are not included in the matrix but are plotted on the graph). Also, some doubtful samples (low carbonate content) and samples polluted by trace elements are used as extra samples. Table 1 shows only the samples used in the matrix calculation (62 samples).

\section{RESULTS}

In Figure 1, sample numbers and variable names are plotted in the first factorial space. The scale of coordinates and percentage inertia ${ }^{2}$ of each axis are given. The first factorial plane explains $76 \%$ of the variability (Factor 1: $54.8 \%$, Factor 2: $21.2 \%$ ).

\footnotetext{
${ }^{1}$ Barker, P. F., Carlson, R. L., Johnson, D. A., et al., Init. Repts. DSDP, 72: Washington (U.S. Govt. Printing Office). 2 If $\lambda_{1}$ is the characteristic value of Axis 1, then $\lambda_{1}+\lambda_{2}+\lambda_{3}+\ldots . \lambda_{p}$ represents the
total inertia of the cloud. The inertia percentage for Axis 1 equals

For more details, see Teil (1975).
}

Table 2 contains the coordinates of variables relative to the first and second axes, and the coordinates of samples are listed in Table 3. Factor 1 (horizontal axis) is polarized both by manganese and strontium (and less by sodium). Factor 2 (vertical axis) is polarized, on the one hand, by magnesium, nickel, chromium, and iron. On the other hand, it is polarized by strontium and (in a less significant way) manganese. Part of the variability along Factor 2 is due to the inverse relationship of the magnesium and the strontium contents of the carbonates. This is probably caused by increasing diagenesis in the pelagic carbonates (Renard, 1979; Rabussier, 1980).

The correspondence analysis method is important for geochemical studies because it is possible to draw a curve that joins sample points in stratigraphic succession; the investigator, therefore, can follow the geochemical evolution of series during geologic time.

\section{Coniacian to Santonian Samples}

The first part of the series studied, Coniacian to Santonian samples, varies along a diagonal line from the manganese pole to the chromium, nickel, iron, and magnesium pole. From Sample 516F-125-1, 24-26 cm to Sample 516F-119-3, 85-87 cm (251 to 193, Fig. 1), there is a progressive displacement from the manganese pole.

There are several oscillations in between Sections 516F-119-1 and 516F-113-3. Between the manganese pole (Samples 516F-119-1, 119-121 cm; 516F-118-3, 14-16 $\mathrm{cm}$; $516 \mathrm{~F}-117-1,132-134 \mathrm{~cm}$; and 516F-114-1, 109-111 $\mathrm{cm}$ ) and the iron-magnesium pole (Samples 516F-120-1, $36-38 \mathrm{~cm}$; $516 \mathrm{~F}-119-3,85-87 \mathrm{~cm}$; 516F-116-3, 31-33 $\mathrm{cm}$; and $516 \mathrm{~F}-117-6,16-18 \mathrm{~cm}$ ), manganese values are always less than in stratigraphically lower samples. These oscillations suggest that geochemical evolution during the Santonian was controlled principally by the opposing behavior of iron and manganese. Seafloor spreading (which produces volcanism and/or hydrothermal emission through sediments) and the removal of the site from the region of hydrothermal circulation are the main causes of variation in the geochemistry of sediments. Alternating iron-rich and manganese-rich periods during the Santonian may reflect variations in the chemical composition of oceanic hydrothermal exhalation. Such fluctuations are observed along mid-oceanic ridges today (Edmond et al., 1979).

\section{Campanian to Eocene Samples}

Beginning with Sample 516F-113-3, 51-54 cm (Campanian), samples are distributed primarily along the second factorial axis. The sharp break in the distribution of samples suggests that seafloor spreading did not play a leading role in the geochemistry of sediment after this time. 
Table 1. Trace element content (in ppm) of Hole $516 \mathrm{~F}$ samples used in the matrix calculation.

\begin{tabular}{|c|c|c|c|c|c|c|c|c|c|c|}
\hline $\begin{array}{l}\text { Code for } \\
\text { Figure } 1\end{array}$ & $\begin{array}{l}\text { Core-section } \\
\text { (interval in cm) }\end{array}$ & $\mathrm{CaCO}_{3} \%$ & $\mathrm{Mg}$ & $\mathrm{Na}$ & K & $\mathrm{Mn}$ & $\mathrm{Sr}$ & $\mathrm{Ni}$ & $\mathrm{Cr}$ & $\mathrm{Fe}$ \\
\hline 381 & $38-1,98-100$ & 92.07 & 1292 & 424 & 163 & 215 & 1185 & 7 & 3 & 1702 \\
\hline 391 & $39-1,42-44$ & 87.34 & 1319 & 455 & 224 & 214 & 1266 & 7 & 3 & 1517 \\
\hline 392 & $39-2,37-39$ & 86.31 & 1073 & 491 & 262 & 210 & 1347 & 5 & 3 & 1343 \\
\hline 401 & $40-1,95-97$ & 89.03 & 1274 & 429 & 208 & 188 & 1305 & 3 & 3 & 1314 \\
\hline 471 & $47-1,18-19$ & 89.67 & 1765 & 499 & 208 & 202 & 1160 & 5 & 5 & 1072 \\
\hline 812 & $81-2,101-103$ & 94.01 & 1211 & 444 & 101 & 430 & 591 & 2 & 3 & 1144 \\
\hline 831 & $83-1,2-5$ & 91.30 & 1687 & 523 & 190 & 370 & 652 & 5 & 2 & 1727 \\
\hline 833 & $83-3,10-12$ & 87.45 & 1252 & 381 & 233 & 655 & 774 & 8 & 3 & 1204 \\
\hline 835 & $83-5,24-26$ & 89.18 & 882 & 556 & 221 & 495 & 977 & 3 & 3 & 1079 \\
\hline 843 & $84-3,80-82$ & 84.80 & 2294 & 623 & 225 & 688 & 990 & 3 & 2 & 2806 \\
\hline 851 & $85-1,51-53$ & 87.40 & 770 & 569 & 180 & 790 & 1033 & 1 & 1 & 1052 \\
\hline 855 & $85-5,100-102$ & 88.75 & 2473 & 389 & 122 & 547 & 1015 & 4 & 1 & 1919 \\
\hline 863 & $86-3,140-141$ & 87.43 & 3195 & 593 & 209 & 567 & 1030 & 7 & 2 & 2734 \\
\hline 866 & $86-6,26-28$ & 88.61 & 2695 & 396 & 112 & 545 & 1029 & 3 & 1 & 1987 \\
\hline 873 & $87-3,105-107$ & 88.78 & 4316 & 383 & 109 & 636 & 838 & 4 & 1 & 2233 \\
\hline 874 & $87-4,3-5$ & 89.66 & 3925 & 523 & 114 & 734 & 739 & 5 & 2 & 2387 \\
\hline 875 & $87-5,96-98$ & 86.44 & 2698 & 441 & 140 & 651 & 723 & 3 & 1 & 1671 \\
\hline 881 & $88-1,102-103$ & 88.44 & 1373 & 471 & 125 & 484 & 621 & 1 & 1 & 824 \\
\hline 891 & $89-1,55-57$ & 78.80 & 1748 & 419 & 206 & 699 & 653 & 2 & 2 & 1227 \\
\hline 896 & $89-6,54-56$ & 82.07 & 2506 & 330 & 198 & 850 & 804 & 3 & 4 & 1624 \\
\hline 901 & $90-1,66-68$ & 79.04 & 1644 & 310 & 226 & 607 & 948 & 2 & 4 & 1290 \\
\hline 902 & $90-2,52-56$ & 73.64 & 2354 & 322 & 303 & 679 & 945 & 4 & 4 & 1800 \\
\hline 904 & $90-4,99-100$ & 81.61 & 2820 & 365 & 162 & 558 & 731 & 3 & 3 & 2032 \\
\hline 905 & $90-5,40-42$ & 81.53 & 2477 & 401 & 172 & 696 & 724 & 3 & 4 & 1988 \\
\hline 906 & $90-6,14-16$ & 82.53 & 2790 & 282 & 161 & 746 & 751 & 2 & 4 & 2050 \\
\hline 911 & $91-1,49-50$ & 76.84 & 2551 & 311 & 209 & 643 & 728 & 3 & 4 & 1902 \\
\hline 912 & $91-2,145-147$ & 81.49 & 2717 & 376 & 195 & 630 & 796 & 3 & 4 & 2079 \\
\hline 913 & $91-3,126-128$ & 78.48 & 3733 & 356 & 238 & 582 & 737 & 3 & 4 & 2630 \\
\hline 914 & $91-4,51-53$ & 81.42 & 3942 & 397 & 194 & 510 & 768 & 5 & 4 & 2822 \\
\hline 933 & $93-3,127-129$ & 77.07 & 1305 & 629 & 267 & 810 & 747 & 1 & 4 & 1158 \\
\hline 935 & $93-5,12-14$ & (4) 20 & 2051 & 549 & 1197 & 761 & 884 & 7 & 6 & 834 \\
\hline 972 & $97-2,64-65$ & 52.89 & 3128 & 473 & 938 & 1265 & 862 & 12 & 11 & 3225 \\
\hline 982 & $98-2,82-83$ & 58.47 & 3419 & 404 & 742 & 1081 & 729 & 19 & 6 & 3595 \\
\hline 042 & $104-2,122-125$ & 68.23 & 5366 & 339 & 292 & 835 & 933 & 7 & 5 & 4958 \\
\hline 051 & $105-1,42-44$ & 68.54 & 4426 & 261 & 225 & 855 & 820 & 6 & 6 & 4086 \\
\hline 055 & $105-5,72-74$ & 57.17 & 1010 & 240 & 322 & 978 & 861 & 4 & 6 & 1850 \\
\hline 062 & $106-2,65-67$ & 71.65 & 766 & 242 & 168 & 855 & 818 & 2 & 4 & 1219 \\
\hline 066 & $106-6,68-70$ & 67.28 & 1372 & 286 & 260 & 883 & 626 & 4 & 4 & 2016 \\
\hline 077 & $107-7,40-43$ & 246 & 1197 & 270 & 290 & 804 & 736 & 4 & 5 & 1480 \\
\hline 084 & $108-4,44-45$ & 63.08 & 2522 & 295 & 297 & 677 & 719 & 6 & 7 & 3070 \\
\hline 093 & $109-3,75-77$ & 75,22 & 3679 & 251 & 235 & 636 & 684 & 7 & 6 & 4730 \\
\hline 094 & $109-4,41-43$ & 1.63 & 2340 & 243 & 281 & 574 & 739 & 6 & 6 & 3234 \\
\hline 133 & $113-3,51-54$ & 30 & 4779 & 456 & 428 & 672 & 567 & 14 & 14 & 5657 \\
\hline 141 & $114-1,109-111$ & 82.62 & 1393 & 198 & 97 & 922 & 310 & 4 & 5 & 2055 \\
\hline 146 & $114-6,116-118$ & 07 & 2908 & 262 & 172 & 773 & 383 & 7 & 8 & 3400 \\
\hline 154 & $115-4,27-2$ & 69.40 & 2137 & 324 & 190 & 881 & 319 & 7 & 8 & 2888 \\
\hline 161 & $116-1,125-12$ & 76.6 & 3187 & 315 & 127 & 770 & 314 & 9 & 8 & 4045 \\
\hline 163 & $116-3,31-33$ & 40.83 & 4602 & 526 & 582 & 614 & 600 & 17 & 21 & 6268 \\
\hline 166 & $116-6,60-62$ & 77.32 & 3219 & 274 & 161 & 758 & 371 & 8 & 8 & 4232 \\
\hline 171 & $117-1,132-13$ & 79.04 & 1840 & 279 & 164 & 920 & 332 & 4 & 6 & 2665 \\
\hline 174 & $117-4,22-24$ & (7) & 2626 & 359 & 260 & 685 & 466 & 7 & 11 & 3702 \\
\hline 176 & $117-6,16-18$ & 6 & 3199 & 345 & 344 & 640 & 445 & 10 & 10 & 4678 \\
\hline 181 & $118-1,123-125$ & & 2893 & 230 & 120 & 769 & 260 & 5 & 6 & 3696 \\
\hline 183 & $118-3,14-16$ & 85.3 & 1335 & 187 & 117 & 694 & 260 & 2 & 5 & 2122 \\
\hline 191 & $119-1,119-121$ & 79.1 & 1334 & 25 & 165 & 800 & 353 & 3 & 7 & 2252 \\
\hline 193 & $119-3,85-8$ & & 3405 & 321 & 169 & 617 & 355 & 8 & 11 & 5339 \\
\hline 201 & $120-1,36-38$ & 65.2 & 4084 & 371 & 126 & 773 & 384 & 9 & 18 & 5922 \\
\hline 211 & $121-1,61-63$ & & 2645 & 305 & 73 & 1126 & 270 & 4 & 12 & 3136 \\
\hline 222 & $122-2,120-122$ & 56.36 & 3286 & 378 & 76 & 1935 & 317 & 4 & 17 & 3088 \\
\hline 231 & $123-1,53-55$ & & 1426 & 311 & 67 & 4538 & 393 & 6 & 19 & 1134 \\
\hline 241 & $124-1,20-22$ & 76.23 & 4516 & 401 & 216 & 4171 & 162 & 2 & 5 & 4184 \\
\hline 251 & $125-1,24-26$ & 39.96 & 3893 & 305 & 1246 & 3644 & 267 & 1 & 6 & 1563 \\
\hline
\end{tabular}

Table 2. Element coordinates relative to first and second factors.

\begin{tabular}{lrr}
\hline Element & Factor 1 & Factor 2 \\
\hline Magnesium & 0.039 & -0.317 \\
Strontium & 0.442 & 0.179 \\
Sodium & 0.254 & 0.051 \\
Potassium & 0.080 & -0.020 \\
Manganese & -0.495 & 0.134 \\
Iron & 0.005 & -0.490 \\
Nickel & 0.140 & -0.427 \\
Chromium & -0.205 & -0.431 \\
\hline
\end{tabular}

Table 3. Coordinates of Hole $516 \mathrm{~F}$ samples relative to first and second factors.

\begin{tabular}{|c|c|c|}
\hline $\begin{array}{c}\text { Core-section } \\
\text { (interval in cm) }\end{array}$ & Factor 1 & Factor 2 \\
\hline $38-1,98-100$ & 0.625 & 0.168 \\
\hline $39-1,42-44$ & 0.640 & 0.197 \\
\hline $39-2,37-39$ & 0.666 & 0.256 \\
\hline $40-1,95-97$ & 0.682 & 0.260 \\
\hline $47-1,18-19$ & 0.623 & 0.185 \\
\hline $81-2,101-103$ & 0.251 & 0.160 \\
\hline $83-1,2-5$ & 0.334 & 0.042 \\
\hline $83-3,10-12$ & 0.163 & 0.173 \\
\hline $83-5,24-26$ & 0.378 & 0.276 \\
\hline $84-3,80-82$ & 0.146 & 0.016 \\
\hline $85-1,51-53$ & 0.223 & 0.365 \\
\hline $85-5,100-102$ & 0.319 & 0.133 \\
\hline $86-3,140-141$ & 0.319 & 0.017 \\
\hline $86-6,26-28$ & 0.324 & 0.126 \\
\hline $87-3,105-107$ & 0.186 & -0.025 \\
\hline $87-4,3-5$ & 0.120 & -0.026 \\
\hline $87-5,96-98$ & 0.150 & 0.092 \\
\hline $88-1,102-103$ & 0.267 & 0.252 \\
\hline $89-1,55-57$ & 0.083 & 0.179 \\
\hline $89-6,54-56$ & 0.041 & 0.133 \\
\hline $90-1,66-68$ & 0.241 & 0.216 \\
\hline $90-2,52-56$ & 0.193 & 0.115 \\
\hline $90-4,99-100$ & 0.187 & 0.010 \\
\hline $90-5,40-42$ & 0.105 & 0.058 \\
\hline $90-6,14-16$ & 0.058 & 0.053 \\
\hline $91-1,49-50$ & 0.119 & 0.042 \\
\hline $91-2,145-147$ & 0.169 & 0.040 \\
\hline $91-3,126-128$ & 0.165 & -0.091 \\
\hline $91-4,51-53$ & 0.226 & -0.133 \\
\hline $93-3,127-129$ & 0.107 & 0.237 \\
\hline $93-5,12-14$ & 0.182 & 0.116 \\
\hline $97-2,64-65$ & -0.026 & -0.028 \\
\hline $98-2,82-83$ & -0.015 & -0.125 \\
\hline $104-2,122-125$ & 0.100 & -0.216 \\
\hline $105-1,42-44$ & 0.033 & -0.171 \\
\hline $105-5,72-74$ & -0.018 & 0.196 \\
\hline $106-2,65-67$ & 0.012 & 0.298 \\
\hline $106-6,68-70$ & -0.070 & 0.110 \\
\hline $107-7,40-43$ & 0.021 & 0.174 \\
\hline $108-4,44-45$ & 0.088 & -0.095 \\
\hline $109-3,75-77$ & 0.082 & -0.298 \\
\hline $109-4,41-43$ & 0.144 & -0.120 \\
\hline $113-3,51-54$ & 0.063 & -0.436 \\
\hline $114-1,109-111$ & -0.361 & 0.007 \\
\hline $114-6,116-118$ & -0.146 & -0.261 \\
\hline $115-4,27-29$ & -0.224 & -0.159 \\
\hline $116-1,125-127$ & -0.159 & -0.361 \\
\hline $116-3,31-33$ & 0.102 & -0.477 \\
\hline $116-6,60-62$ & -0.132 & -0.354 \\
\hline $117-1,132-134$ & 0.271 & -0.075 \\
\hline $117-4,22-24$ & -0.023 & -0.261 \\
\hline $117-6,16-18$ & 0.003 & -0.382 \\
\hline $118-1,123-125$ & -0.241 & -0.329 \\
\hline $118-3,14-16$ & -0.282 & -0.078 \\
\hline $119-1,119-121$ & -0.223 & -0.034 \\
\hline $119-3,85-87$ & -0.052 & -0.507 \\
\hline $120-1,36-38$ & -0.106 & -0.520 \\
\hline $121-1,61-63$ & -0.393 & -0.162 \\
\hline $122-2,120-122$ & -0.561 & -0.015 \\
\hline $123-1,53-55$ & -0.945 & 0.365 \\
\hline $124-1,20-22$ & -0.863 & 0.167 \\
\hline $125-1,24-26$ & -0.675 & 0.212 \\
\hline
\end{tabular}




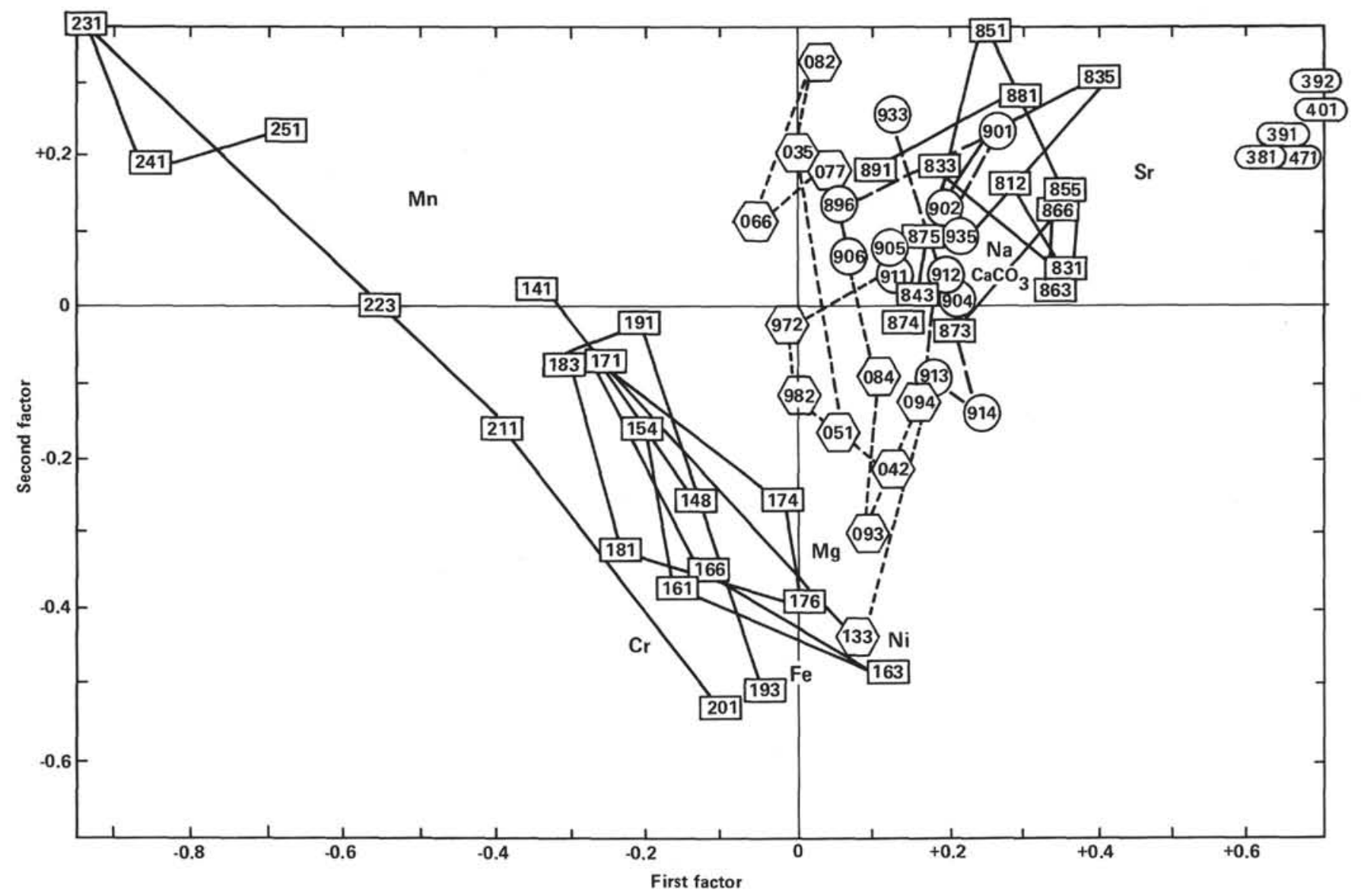

Figure 1. Analysis of samples from Cores 125 to 38 (Coniacian to Eocene samples) of Hole 516F. For sample number code, see Table 1. In Figure 2, these numbers are enclosed in different geometric figures corresponding to major time groups. Rectangles $(141-251)=$ Coniacian to Santonian; hexagons = Campanian; circles = Maestrichtian; rectangles $(812-891)=$ Paleocene; ovals = Eocene.

We can distinguish three groups in the Campanian section between Samples $516 \mathrm{~F}-113-3,51-54 \mathrm{~cm}$ and $516 \mathrm{~F}-97-2,64-65 \mathrm{~cm}$. The first group (chiefly Campanian samples with high magnesium and iron content) occupies the lower part of the graph in Figure 2. Samples $516 \mathrm{~F}-97-2,64-65 \mathrm{~cm}$ to $516 \mathrm{~F}-98-2,82-83 \mathrm{~cm}$ (low iron values) comprise the second group, which shows up in the middle section of the graph. In the upper part of the graph is the third Campanian group, which consists of samples with low magnesium and iron values (Samples $516 \mathrm{~F}-107-7,40-43 \mathrm{~cm}$; $516 \mathrm{~F}-106-2,65-67 \mathrm{~cm}$; and $516 \mathrm{~F}-105-5,72-74 \mathrm{~cm})$. Strontium values do not fluctuate and are not particularly high compared to other Campanian samples.

Maestrichtian samples (516F-93-5, $12-14 \mathrm{~cm}$ to $516 \mathrm{~F}$ $89-6,54-56 \mathrm{~cm}$ ) are plotted near the strontium pole on Figure 2. The low positions of two samples (516F-91-3, $126-128 \mathrm{~cm}$ and $516 \mathrm{~F}-91-4,51-53 \mathrm{~cm}$ ) are chiefly the result of a high magnesium content (perhaps contamination by interlayer magnesium of clay minerals) and seem atypical. The extreme position of Sample 516F-90-1, 66-68 cm, however, which is related to high strontium and to low magnesium and iron values, suggests a special geochemical condition during the Paleocene.

Very close to the strontium pole in Figure 2 are the symbols for Paleocene Samples 516F-89-1, 55-57 cm to
516F-81-2, 101-103 cm. The lower positions of five samples (Samples 516F-84-3, 80-82 cm; 516F-87-4, 3-5 $\mathrm{cm}$; $516 \mathrm{~F}-87-3,105-107 \mathrm{~cm}$; $516 \mathrm{~F}-87-5,96-98 \mathrm{~cm}$; and $516 \mathrm{~F}-89-1,55-57 \mathrm{~cm}$ ) are related to high iron and relatively low strontium contents. Samples very close to the Cretaceous/Tertiary boundary have not been plotted; the results of their analyses are particularly unreliable because of their low carbonate content. Although Danian samples are distinguished from Thanetian samples by their strontium values (Renard, this volume), they are not identified by the correspondence analysis method, even on Axis 3 (perpendicular to the plane defined by Axes 1 and 2, and not shown on our projection). Apparently, iron variability camouflages other geochemical variations in the Tertiary series.

Eocene Samples $516 \mathrm{~F}-47-1,18-19 \mathrm{~cm}$ to $516 \mathrm{~F}-38-1$, 98-100 $\mathrm{cm}$ are plotted as preliminary data and are located beyond the strontium pole. This location indicates that they are different from the other samples discussed.

\section{CONCLUSION}

Correspondence analysis allows a simultaneous global treatment of all geochemical parameters of Coniacian-Eocene sediments from Hole 516F. The synthesis graph (Fig. 2), which summarizes the geochemical evolution of the series, leads to the following conclusions. 


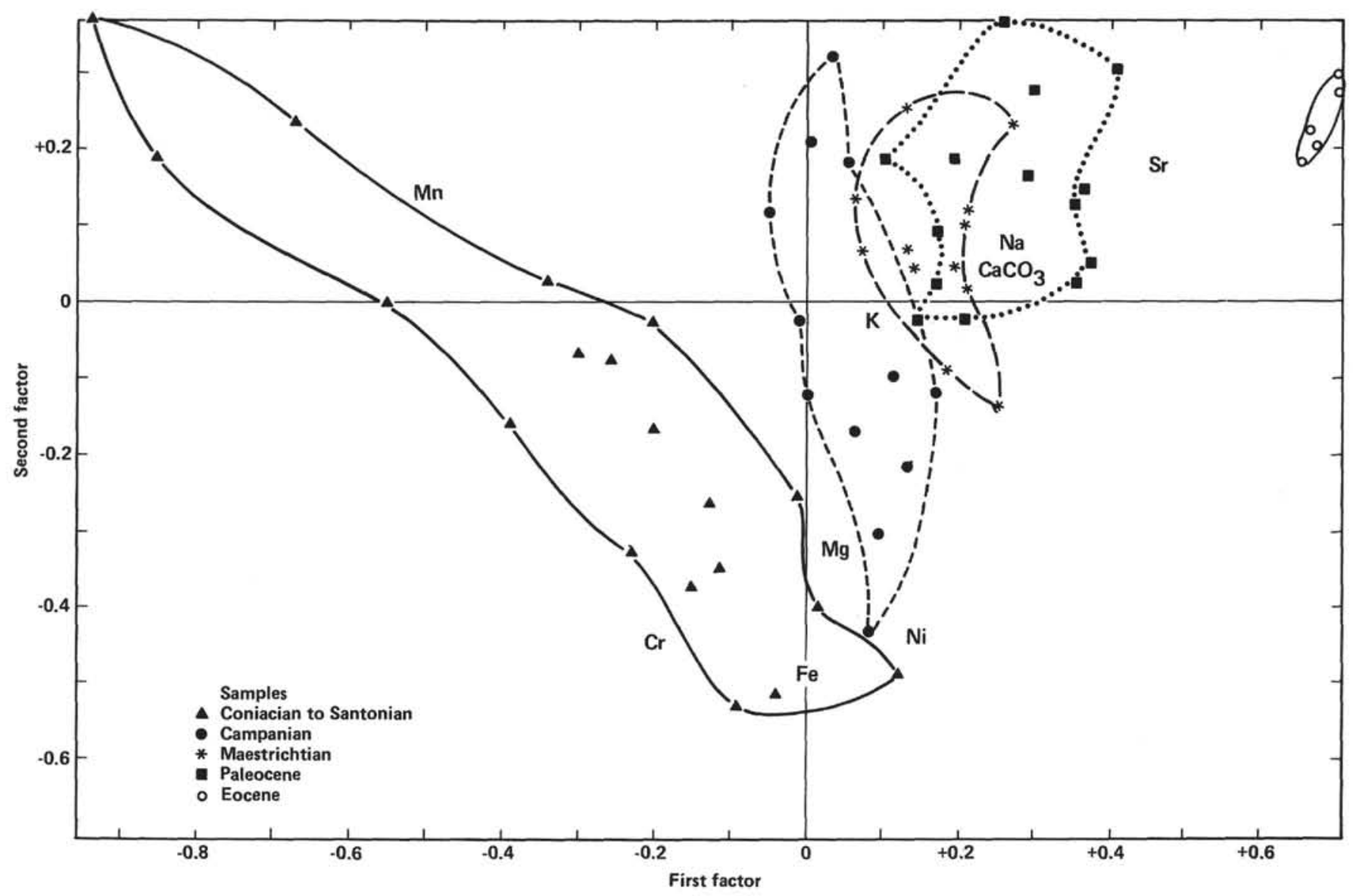

Figure 2. Schematic evolution of Coniacian to Eocene sedimentary geochemistry (Hole 516F). For sample identification, refer to Figure 1.

1) Each time stage has a very well defined area; each can be easily characterized by its geochemistry.

2) During the Coniacian to Santonian, manganese was the dominant geochemical constituent; this suggests that the geochemical evolution of sediments from that interval is mainly controlled by seafloor spreading;

3) After the Campanian, there was a sharp change in the control of the geochemical evolution of sediments. This evolution is now mainly controlled by chemical variations of the sedimentary environment and by diagenetic phenomena.

\section{ACKNOWLEDGMENTS}

We are grateful to M. Michel Petzold for preparation of figures, to Mrs. Monnier and Mrs. Demond for typing the manuscript, and to Dr. J. Limond and S. Taylor for their critical reading of the text. Many thanks are also due to Dr. W. Coulbourn for his constructive criticisms and his help in English translation. Funds for this research were provided by Centre National de la Recherche Scientifique through Action Thematique Programmé, IPOD, and Géologie et Géophysique des Océans. Calculations were carried out on IRIS 80 CII.HB computer of the Atelier d'Informatique of Paris University.

\section{REFERENCES}

Ambroise, D., Azéma, J., Chaye D'Albissin, M., Foucault, A., Fourcade, E., Leikine, M., Mélières, F., Movchet, J., and Renard, M., 1977. Le crétace inférieur du Monte major d'Ayora. Essai sur les conditions de sédimentation. Bull. Soc. Geol. Fr., 19(6): 1275-1284.
Benzecri, J. P., 1972. L'analyse des Données. L'analyse des Correspondance (Vol. 2): Paris (Dunod).

Chenet, P. Y., and Teil, H., 1979. Study of some samples of Hole 398D, Leg 47B, with the correspondence analysis methods. In Sibuet, J.-C., Ryan, W. B. F., et al., Init. Repts. DSDP, 47, Pt. 2: Washington (U.S. Govt. Printing Office), 469-474.

Edmond, J. M., Measures, C., McDuff, R. E., Chan, L. H., Collier, R., Grant, B., Gordon, L. I., and Corliss, J. B., 1979. Ridge crest hydrothermal activity and the balance of the major and minor elements in the ocean: the Galapagos data. Earth Planet. Sci. Lett., 46:1-18.

Lebart, L., Morineau, A., and Fenelon, J. P., 1980. Traitements des données statistiques: Paris (Dunod).

Rabussier Lointier, D., 1980. Variations de composition isotopique de l'oxygène et du carbone en milieu marin et coupures stratigraphiques du cenozoique [Thèse de III $^{\text {eme }}$ cycle]. Université $P$. et M. Curie, Paris.

Renard, M., 1979. Aspect géochimique de la diagénése des carbonates. Teneurs en strontium et en magnésium des carbonates: essai d'interprétation de l'inversion de la corrélation $\mathrm{Sr} / \mathrm{Mg}$ observée dans les carbonates du domaine pélagique par rapport à ceux du domaine néritique. Bull. Bur. Rech. Geol. Min. Sec. 4 Fr., 2: 133-152.

Teil, H., 1975. Correspondence analysis: an outline of the method. J. Math. Geol., 4:1-7.

Tourenq, J., Ambroise, D., and Rohrlich, V., 1979. Sables et argiles du Bourbonnais: mise en évidence des relations entre les minéraux lourds à l'aide de l'analyse factorielle des correspondances. Bull. Soc. Geol. Fr., 20(5):733-737.

Date of Initial Receipt: January 6, 1982 